\title{
ON LANGUAGE AND ITS LIMITS
}

SOBRE A LÍNGUA E SEUS LIMITES

SOBRE EL LENGUAJE Y SUS LÍMITES

\author{
Adrian Pablé* \\ University of Hong Kong
}

\begin{abstract}
I consider three positions regarding the limits of language: two (mutually incompatible) 'segregational' approaches, which I will contrast with the 'integrational' approach advocated by Roy Harris. I shall argue that an integrationist construal of the limits of language cannot be dissociated from the Harrisian concept of 'radical indeterminacy'. The latter notion is highly controversial within the linguistic orthodoxy, as it sponsors the idea that 'languages' qua describable objects are theoretically redundant. In other words, human communication does not involve 'languages' from an integrational point of view. However, it is the very notion of 'a language' which makes it possible for linguists and philosophers to discuss the limits of language in the first place. My position, in turn, is that the notion of English (German, etc.) as having limits originates in decontextualized analyses at both, the lay and professional levels of linguistic inquiry. I thus support the thesis that the limits of language cannot be contemplated independently of the human communicational infrastructure and that these limits are co-extensive with personal linguistic experience.
\end{abstract}

KEYWORDS: Segregational approach. Integrational approach. Language. Radical indeterminacy.

RESUMO: Considero três posições sobre os limites da linguagem: duas abordagens "segregacionistas" (mutuamente incompatíveis), que contrastarei com a abordagem "integracionista" defendida por Roy Harris. Defendo que uma interpretação integracionista dos limites da linguagem não pode ser dissociada do conceito harrisiano de "indeterminação radical". Esta noção é altamente controversa dentro da ortodoxia linguística, uma vez que veicula a ideia de que "línguas" enquanto objetos descritíveis são teoricamente redundantes. Em outras palavras, a comunicação humana, para um ponto de vista integracionista, não envolve "línguas". No entanto, é a própria noção de "uma língua” que torna possível para linguistas e filósofos discutir os limites da linguagem em primeiro lugar. Minha posição, por sua vez, é que a noção de inglês (alemão etc.) como tendo limites se origina em análises descontextualizadas, tanto no nível leigo quanto profissional, da investigação linguística. Assim, apoio a tese de que os limites da linguagem não podem ser contemplados independentemente da infraestrutura comunicativa humana e que esses limites são coextensivos à experiência linguística pessoal.

PALAVRAS-CHAVE: Abordagem segregacionista. Enfoque integrador. Linguagem. Indeterminação radical.

RESUMEN: Considero tres posiciones sobre los límites del lenguaje: dos enfoques "segregacionistas" (mutuamente incompatibles), que contrastaré con el enfoque "integracionista" defendido por Roy Harris. Sostengo que una interpretación integracionista de los límites del lenguaje no puede disociarse del concepto harrisiano de "indeterminación radical”. Esta noción es muy controvertida dentro de la ortodoxia lingüística, ya que transmite la idea de que las "lenguas" como objetos descriptibles son teóricamente redundantes. En otras palabras, la comunicación humana, desde un punto de vista integracionista, no implica "lenguas". Sin embargo, es la misma noción de "una lengua" la que hace posible que los lingüistas y filósofos discutan los límites del

\footnotetext{
*Associate Professor of English at the University of Hong Kong and Professor Extraordinarius at the University of South Africa (Pretoria). He is the Secretary of the International Association for the Integrational Study of Language and Communication (IAISLC) and series editor of the Routledge Advances in Communication and Linguistic Theory, previouslyedited by Oxford Professor Roy Harris. E-mail: apable@hku.hk.
} 
lenguaje en primer lugar. Mi posición, a su vez, es que la noción de que el inglés (alemán, etc.) tiene límites se origina en análisis descontextualizados, tanto a nivel lego como profesional, de la investigación lingüística. Por tanto, apoyo la tesis de que los límites del lenguaje no se pueden contemplar independientemente de la infraestructura comunicativa humana y que estos límites son coextensivos con la experiencia lingüística personal..

PALABRAS CLAVE: Enfoque segregacional. Enfoque integrador. Lenguaje. Indeterminación radical.

\section{PREFATORY REMARKS}

If we accept that self-knowledge is the ultimate goal of the human intellectual quest, the task requires some understanding of human potentialities and limitations. One question we might wish to ask on that score would be: What are the limits of the human mind? If we further concede that 'language' plays a pivotal role in how we understand ourselves as a species, we may proceed to ask whether there are limits to human language, and what exactly this entails. Mainstream linguistics has set these limits around the notion of 'a language', ontologically conceived as a system of mutually dependent linguistic signs (as postulated by Saussure), or as generative rules of sentence formation (as envisaged by Chomsky), where the notion of 'the sign', while tacitly assumed, is no longer part of theoretical linguistics. In mainstream philosophy of language, the limits of language stretch as far as the everexpanding boundaries of material reality: linguistic statements are thus assessed according to their truth-values. At the opposite end of the spectrum, the Oxford linguist Roy Harris has proposed a radically different thesis on human language and its limits, including how language relates to what lies outside language. It is a view based on a semiological position that treats signs as radically indeterminate in both form and meaning (HARRIS; HUTTON, 2007). Harris' critical exploration of the limits of language was set up under the aegis of 'integrational linguistics' (HARRIS, 1998). Integrationists regard communication as a time-bound activity, itself comprising many other time-bound activities (e.g. speaking, listening, gesturing, thinking). All of these activities, the integrationist argues, need to be integrated via signs by the human sign-makers at some level in order for communication to occur. Integration in the here-and-now presupposes the activation of personal past experience as well as the projection of personal future experience: no two individuals' sign-making is ever the same because no two individuals share the same communicational history. Human memory and human imagination thus set limits to language, both individually and for the human species. Crucially, for Harris, there is no other basis for a communication theory than the first-order, which, translated into semiological terms, simply means that there are no abstract signs in the here-and-now - only personal signs. Such a position has consequences on how the limits of language are charted. However, as a result of linguistic reflexivity (HARRIS, 1998, p. 25), human beings are given to decontextualizing language, resulting in beliefs (among the members of the professional linguistic community) subsumed by Harris under the 'Language Myth' label (HARRIS, 1981). Hence the orthodox assumption that an inquiry into the limits of language requires a 'scientific' approach.

This contribution considers three positions regarding the limits of language: two (mutually incompatible) 'segregational' paradigms, namely the "reocentric surrogational" approach (HARRIS, 1980) and the Saussurean-mentalist approach, which it contrasts with the integrationist approach. I shall argue that an integrationist construal of the limits of language cannot be dissociated from the concept of "radical indeterminacy" (HARRIS, 2009, p. 81). The latter notion is highly controversial within the linguistic orthodoxy, as it sponsors the idea that 'languages' qua describable objects are theoretically redundant. In other words, human communication does not involve 'languages' from an integrational point of view. However, it is the very notion of 'a language', i.e the limits posed by it, which make it possible for linguists and philosophers to discuss the limits of language in the first place. As the integrationist argues, the idea that English has limits (e.g. there are limits to what constitutes an English word: qrwxzy is not an English word) has its origins in - and is further reinforced by - decontextualized analyses at both the lay and professional levels of linguistic inquiry. The present paper will argue in favour of the thesis that the limits of language cannot be contemplated independently of the human "communicational infrastructure" (HARRIS, 1996, p. 12) and that these limits are coextensive with personal linguistic experience. 


\section{LOWER AND UPPER LIMITS TO LANGUAGE}

In the work of Roy Harris, there are several passages discussing the idea that language and communication have limits. The most thorough treatment features in the book History, Science and the Limits of Language (HARRIS, 2003). Moreover, Harris refers to this topic in a number of Integrationist Notes and Papers, e.g. such as when stating that "[...] integrationism places no a priori limit on what can be integrated in the process of communication" (2013, p. 101). Or when he asks: "What are the minimum beliefs for linguistic inquiry?" (HARRIS, 2014, p. 63), where the 'minimum beliefs' could be interpreted as referring to the 'lower limits'. According to Harris (2014, p. 66), linguistic inquiry does not have to start with defining 'a language'. Thus, belief in 'languages' does not count as a sensible lower limit for linguistic inquiry. Instead, Harris prefers a much more basic approach, namely that the minimum beliefs required for linguistic inquiry are (a) that it is possible to ask questions and (b) that to every question there is at least one possible answer (HARRIS, 2014, p. 64). Asking questions, according to Harris, is without limits, at least in the sense that there are no 'ultimate' questions (HARRIS, 2011). The day human beings stop asking questions is the day that humans cease to exist. Of course, we can refuse to ask questions, just as we can refuse to give answers. Harris (2012a, p. 83) proposes to call human beings "the questioning animal" (which he prefers to Aristotle's 'rational animal'). "The human being", he claims, "is a creature that can ask questions", to which he adds: "Unless we understand this latter capacity, we understand very little about human nature". Harris (2012a, p. 84) goes on to state that the questions that have been asked in linguistics and in philosophy of language have received answers underwritten by simplistic assumptions. These assumptions are premised on what Harris (1981) has called the 'Language Myth'.

In the Introduction to Integrational Linguistics (HARRIS, 1998), the reader encounters several passages referring to the limits of understanding and the limits of communication. Here are some examples:

So understanding itself $[\ldots]$ is limited by what, at any given time, participants are aware of and how they contextualize this in relation to past and (projected) future experience. (HARRIS, 1998, p.105)

Integrationism recognizes no limit to what might - or might not - be pertinent to linguistic communication in specific cases. (HARRIS, 1998, p 41)

For the integrationist, the possibilities and limits of human communication, both in general and in any given instance, are governed by three kinds of factor: biomechanical, macrosocial and circumstantial. (HARRIS, 1998, p. 29)

Why is it important for Harris to ponder the question of the limits of language and of linguistic communication? I think it matters to him because the question tells us something about human nature, in other words, it is a question that takes us a step further towards self-knowledge. Understanding human nature, for Harris, is bound to how we think about language. To Harris, it does matter how you think about language, or as he puts it: "[... if you want to understand human nature, it is important to get your philosophy of language right" (HARRIS, 2003, p. 83). Different philosophies of language will thus lead to different understandings of human nature. So it does make a difference how we apply the term 'language', and Harris notes that "there are limits to how people are prepared to apply that term" (2003, p. 83). We may surmise that this is the case in any human cultural context. Harris' insight was recently elevated to a central question within Southern linguistic theory (e.g. PENNYCOOK; MAKONI, 2019; HAUCK; HEURICH, 2018), which explores the idea of radical differences between the 'Global South' and the 'Global North' in terms of the upper an lower limits of language. Severo and Makoni (2021), for instance, argue that songs may need to be part of linguistic analysis in southern contexts. In fact, integrationists claim that there is no hard-and-fast line separating 'linguistic' activities from 'non-linguistic' activities. What would be the basis for such a distinction? Drawing such distinctions is indeed the hallmark of all 'segregational' theories of language, which Harris contrasts with his own 'integrational' approach (HARRIS, 1996). Nevertheless, Harris (2003, p.82) argues that "language has its limits". The limit that Harris sets as the 'lower limit' of language is what he calls "proto-numeracy". Grasping proto-numerical differences (such as the difference between 'one' and 'many') enables us to recognize words in the first place, and to make distinctions between what grammarians have traditionally called proper names and common nouns. Grasping the basic proto-numerical concepts is a precondition for linguistic abilities like 
individuation, itemization, classification, setting up correspondences, and establishing equivalences (HARRIS, 2003, p. 77). The simplest forms of verbal communication, Harris tells us, require proto-numeracy.

\section{THE LIMITS OF 'SEGREGATIONAL' PHILOSOPHIES OF LANGUAGE}

In his book (HARRIS, 2003), Harris considers different ways in which language could be construed as having limits. One such way is the common notion, corresponding to a Whorfian stance, that "[...] my language has limits insofar as there is no way I can ask questions about anything I do not have words for" (HARRIS, 2003, p. 18), i.e. my language sets boundaries to my world (to what I can perceive and where the boundaries of my thought lie). From this, Harris (2003, p.19) concludes: "My intellectual inquiry is bounded by the questions my language allows me to ask. Intellectual resources and linguistic resources are co-extensive: one does not exceed the other".

A more radical interpretation of how your language has limits, Harris tells us, would be one in line with an integrational position: the limits of your language are thus not constraints imposed by the tense system or by the vocabulary of a particular language (in a Whorfian sense), but rather constraints imposed "[...] by what your linguistic community understands a language to be", i.e. how it sees "[...] its language as being related to the non-linguistic world in general" (HARRIS, 2003, p. 20). The example Harris provides is that of an imaginary terrestrial community, in which verbal activities are disconnected from non-verbal activities in a way that runs counter to our everyday linguistic experience. It is, Harris goes on to argue, "as if certain connections between language and the world had been severed". The relation between saying and doing, in that imaginary community, has not been implemented. The science community, with its 'reocentric' approach to words, might count as such a community. It is a community that has come to conceptualize 'a language' as a nomenclature, i.e. as an ever-changing list of words that get their meaning from outside language, namely by 'standing for' the things, states, and processes as they exist as part of external reality. Here we have an example of a conception of language in which words - and verbal statements made with these words - are treated as existing independently of the human activities they integrate in the here-and-now. For Harris, a reocentric conception of how words relate to the non-linguistic world is both limiting and limited (e.g. HARRIS, 2005). At the same time, science has as its task the continuous expansion of human understanding and of its limits. Ever since the publication of Thomas Kuhn's The Structure of Scientific Revolutions (KUHN, 1970), philosophers of science have debated whether scientists possess a common language, one that is constantly changing but at the same time remains the same. However, nobody in the science community - including the philosophers of science - seems to care to define what exactly 'a language' is. Scientists communicate, they agree and disagree with each other, and to do so they would seem to need 'a language' in which to carry out their agreements and disagreements. Some philosophers of science have argued against Kuhn, namely that a common language is not a prerequisite for science communication. For example, Proctor and Capaldi have argued that

[...] the absence of [a common] language in no way precludes scientists who work in different paradigms from communicating with each other. We suggest, for example, that Einstein, in expressing dissatisfaction with certain aspects of quantum mechanics, understood perfectly well the basis of his disagreement. After all, it is common knowledge that people who disagree with each other, even when those disagreements are fundamental, are perfectly capable of understanding what it is they disagree about. (PROCTOR; CAPALDI, 2006, p. 125)

However, in the absence of a common language, one might wonder, what is the basis for such an understanding? The idea seems to be that as long as you know how words correspond to things, i.e. as long as you are able to supply both the old and the new definitions of contested words, you are a speaker of the ever-evolving language of science. So, saying 'what is copper?' is not really 'doing' anything, and neither is replying 'it is a metal having the properties of malleability, fusibility, ductility, electric conductivity, density 8.92, atomic weight 63.54, and atomic number 29'. The 'realist' conception of the language of science likely is an extension of older, lay ways of thinking about language: Words are rooted in talking meaningfully about independently existing things, for which you need shared linguistic labels (SEALEY, 2014). Are there cultures and communities in which linguistic labels are not the names of things (material, immaterial, or whatever other ontology is believed to exist)? Could reocentrism be a universal linguistic 
belief about how words signify, which sets limits to everyone's language? And is this linguistic belief not a direct consequence of our ability to create what Harris calls 'proto-numerate concepts'? This very ability, of course, is in turn linked to biomechanical, species-specific constraints, i.e. the fact that the world, from a human perspective, is made of both countable things and noncountable stuff, which we can compare and classify. We can see and touch those things, some of which we can hold in our hands, pick them up, and put them somewhere else (HARRIS, 2012b). More recently, things that would otherwise be too small to see, or too distant for the naked eye have been made accessible to our senses through artificial enhancement (HARRIS, 2005).

Could an integrationist approach, in turn, shift our understanding of the limits of language in a radically different direction? For instance, does it matter what semiological beliefs I hold when trying to figure out what the limits of language are? The integrationist posits the sign to be radically indeterminate in both form and meaning (HARRIS; HUTTON, 2007). This already marks a radical departure from any mainstream assumptions about the sign, usually conceived as a determinate signifier-signified pair: in other words, the Saussurean sign, which is the sign conception commonly (though mostly tacitly) assumed in orthodox linguistic theory. Saussure developed his semiological theory based on the insight that linguistic signs are psychological units in a system called 'the language' (la langue), which is shared by a collectivity of speakers. This manoeuvre allowed him to 'explain' how speaker A and hearer B communicate with each other, namely by sharing ideas/concepts by means of a common linguistic code. Saussure presented a general model of linguistic communication, which declared some parts of it to be non-observable. In fact, no empirical research can lead the linguist to 'see' signs as biplanar mental units. Saussure's psychological conception of the linguistic sign needs to be interpreted in the light of his rejection of 'languages' as nomenclatures. According to Saussure, successful linguistic communication is premised on speaker A and hearer B sharing the same abstract system of signs, which is in existence prior to any interaction between any real speaker and any real hearer. Without intending to, Saussure addressed John Locke's skeptical argument about communication, which treated it as a matter of speaker and hearer independently attaching their own private ideas to the words uttered or heard, which in turn failed to guarantee mutual understanding. Saussure's 'solution' was to deny that ideas are private or that they have a separate existence from words: Rather, ideas are concepts carved out from the potentiality of human thought, which are tied to sound patterns carved out from the potentiality of human sound, as historically institutionalized by a conscious collectivity.

The Saussurean view is arguably even more limiting than the reocentric view of languages. The former declares that, as far as our linguistic knowledge is concerned, we are 'prisoners' of our internalized language system. I may think I know what a word from another language means, or even a new word that I identify as being a word of my own language, but, from a Saussurean standpoint, I do not really 'know' those words (they are words, not linguistic signs, and thus at the mercy of the individual). Linguistic knowledge is collectively defined. The Saussurean argument thus runs as follows: lay speakers do not actually understand the nature of language. They think they do, but it is no more than an illusion. In fact, they believe that words are surrogates for things, which is what allows them to talk to others (who speak the same language) about that which lies outside of language. In turn, Saussure claims that what 'a language' actually is lies beyond the limits of lay understanding.

\section{LANGUAGE AS UNFATHOMABLE}

The psychologist Philip Johnson-Laird has championed his own version of the Saussurean thesis. He believes that one of the limits of human understanding is precisely "[...] a systematic inability to understand language" (JOHNSON-LAIRD, 2003, p. 4). For example, Johnson-Laird tells us that when we pause to reflect on what conditional if means, we will have to admit that we do not know. Not even philosophers and linguists do, he assures us. So we only "seem to communicate successfully" when using conditional clauses. Following that, Johnson-Laird (2003, p. 33) goes on to argue, we cannot really understand the verb to cause either, as, for instance, in the sentence 'to anger someone is to cause them to become angry'. "Something mysterious is going on", Johnson-Laird (2003, p. 4) concludes. Human understanding, as Johnson-Laird's research endeavours to show, is an illusion, and one that leads us to make errors in reasoning. At the same time, Johnson-Laird assures us that we can "understand a potentially infinite number of distinct sentences" (JOHNSON-LAIRD, 2003, p. 7). Thus, on the one hand, we lack the ability to define perfectly familiar words like conditional if, on the other hand, there is no upper limit for us when it comes to understanding sentences never encountered before. However, our understanding of those sentences is itself an illusion; as soon as you stop to 
analyze what the single words mean, you will realize that meaning is uncertain. Johnson-Laird (2003, p. 41) admits that stopping to analyze a word and not knowing what it means exactly is an "odd phenomenon", which "may not matter in daily life", but he adds that "there are occasions in which it is important to know what we mean". On that score, we might conjecture that Saussure condemned the practice of decomposing words into semantically more transparent units (or folk-etymologizing them) because ultimately he also believed that a full understanding of words is not humanly possible. Hence, Saussure resolved that understanding is something that occurs in interpersonal communication automatically (between speaker A and hearer B - if they share the same system): understanding lies beyond the grasp of the individual's conscious awareness. In a similar vein, JohnsonLaird (2003, p. 25) tells us that "communication succeeds" even though people speak "a language that they do not always understand" (2003, p. 24). If we apply Saussure's theoretical model to Johnson-Laird's model, it is at the level of parole that we do not understand (i.e. when we 'stop to analyze' the words that we and others use), while at the level of langue (the language system) identical mental concepts are triggered in the minds of speaker A and hearer B. Saussure decided that the non-finite nature of meaning at the level of parole was not to concern a linguistics of langue, which he saw as the proper domain of a general linguistics founded on semiological principles. In turn, Johnson-Laird's argument that 'there are occasions in which it is important to know what we mean' is at odds with lay linguistic practices. Usually, we ask others to explain what they mean (e.g. to check if we understood what they mean by the words they used), or we may ask whether they understand what we mean (or we ask ourselves whether the others understand what we mean). However, do we ever pause and wonder whether we know what we ourselves mean?

Our semiology is certainly limited (HARRIS, 1996, p. 109-110): it is a human semiology. However, language is not something that has to be understood beyond itself. Johnson-Laird has no superior view about the essence of language than anyone else in the human community. His psycholinguistic research does not discover something new about human language: it just reaffirms the linguistic biases underlying the whole project. It is the result of thinking about language in a certain limited way. The limitation consists in treating words as already given (at some level of abstraction) and word-meaning (as well as sentence meaning) as something that our mind can never fully grasp. Language has been severed from the human individual who uses language. It is as if Johnson-Laird believed that human beings are not quite up to the linguistic task: We have been equipped with something that we do not fully understand. Nature has put a 'language machine' into our brain that would actually be better suited for more intelligent beings. However, is it not Johnson-Laird's own notion of 'understanding' which creates the limits that allegedly characterize human understanding? In fact, what does understanding, as construed by Johnson-Laird, imply? For example, is it supposed to accommodate lay linguistic usage, e.g. when we say about our dogs that they 'understand' us? In what way would dogs 'understand' what we say? At the other extreme, there is the assumption that highly intelligent non-human (non-terrestrial) beings will be less limited in understanding the nature of human language. However, language cannot be grasped experientially outside the human body and mind. We simply do not know how a more intelligent non-human creature would grasp human language. Johnson-Laird (2003, p. 27) is right when he posits that our inability to "understand the mind of a super-intelligent being" is a consequence of human limits. But this is true in general: We are unable to understand the mind of any non-human being, whether more or less intelligent than us. The crux lies with the concept of 'understanding': we can only 'understand' qua human beings. There is no species-neutral understanding. Anthropocentrism and anthropomorphism may be limiting, however, these are the limits we have no choice but to embrace.

\section{THE LANGUAGE OF SCIENCE BETWEEN PHILOSOPHIES OF LANGUAGE}

From an integrationist point of view, the limits of language are not set by language itself or by the limits of the human mind. As mentioned earlier, they are related directly to what we as a community understand 'a language' (or language) to be. Scientists, for example, believe that the limits of language are set by the limits of nature. The word phlogiston, for instance, was taken off the list of scientific names once the theory that a fire-like element is released during combustion was shown to be wrong. Attempts to put phlogiston back on the name list are officially dismissed as 'pseudo-science'. Reocentric science must by definition patrol the boundaries of its contemporary language, however without losing sight of its historical continuity. Thus, what copper 'really' is cannot be completely disengaged from "appeals to knowledge acquired in the past" (HARRIS, 2003, p. 66). For example, copper, as it is defined now, is related to copper as it was (wrongly) conceptualized in proto-scientific times. The reason for this is the word 
copper itself, i.e. its linguistic survival throughout the centuries. In Latin, it was called cuprum, in Old English copor. In German, it is called Kupfer. It is the 'same' word attested in different time periods and across different geographical areas, as comparative philologists will assure us. As Harris (2003, p. 67) hastens to add, however, a reocentric semantics leads to conflating two sets of questions: One is to conflate the question 'What does this word mean?' with the question 'What does this word stand for?'. The second is to conflate the question 'What does this word mean?' with the question 'What is this word's history?'. The respective views of language and how language relates to the world encapsulated in these four questions are limiting in the sense that (i) they assume words to be part of a fixed-code ('a language'), which determines both their form and their lexical meaning; (ii) they assume that words can unproblematically be compared across languages; and (iii) they assume that words designate something outside of language independently of the context. Science, history, the law, and many other institutionalized fields of knowledge rely on a philosophy of language built on precisely these assumptions.

For the scientist, copper obviously is a word of a given language ('English' in this case), but the scientist would not want to concede that what copper means is therefore only ascertainable from within the English language. Copper is a word, yes, but it identifies a thing, and what that thing is does not depend on any linguistic or cultural reality. So the scientist is happy to operate with the notion that there are languages (such as 'English'), whose words are used to identify things in the non-linguistic world - what Harris \& Hutton (2007, p. 212) call a word's "narrow referential focus". However, the scientist is less happy to endorse the structuralist notion of 'a language' as a closed system - e.g. the Saussurean fixed-code, which enables speaker A and hearer B to verbally communicate with each other. But how, then, does the language of science accommodate lexical innovations or semantic changes? Tomorrow's definition of copper might be different from yesterdays' definition of copper in scientific English: The same word, however with a different meaning. As the Saussurean linguist might wonder: Where is the guarantee that two scientists understand the same word in the same way (i.e. attach the same idea) in the absence of a closed system which fixes form and meaning? The reocentric conception of words fails to provide a coherent account of how communication within a community of speakers is possible through the words alone, i.e. without constantly having to make explicit to the others how the words you use are to be understood ('I don't mean vaccine in the traditional sense, I mean vaccine in the sense of 'gene therapy"). In turn, the Saussurean - or structuralist - conception of words (i.e. the linguistic sign) denies that words designate things (meaning is defined internally, not externally), even though nothing in our experience corroborates this distinction between the linguistic sign (the mental fact) and the actual word (the physical and physiological facts). So does science have its own language after all? And if it does not, how can a scientist distinguish, linguistically speaking, between fellow scientists and pseudo-scientists? There thus seem to exist linguistic limits to the language of science, which requires quite a bit of patrolling and policing. Reocentric surrogationalism and Saussurean structuralism cancel each other out, while at the same time requiring each other. Both philosophies of language, however, are somehow needed in order to make any sense, intellectually, of the claim that science has its language'.

\section{UNLIMITED LINGUISTIC EXPERIENCE}

The integrationist holds that signs are 'made' by the sign-maker in relation to a present communicational purpose, namely to integrate various ongoing activities (one's own and other people's) in the here-and-now. Signs have no metaphysical existence, in fact, no existence above and beyond the communicational activities for which they are called into life. The signs required to integrate one activity with another are personal signs, i.e. they require a maker rather than a user. Such a personal sign can only be indeterminate in both form and meaning (HARRIS; HUTTON, 2007). Indeterminate signs in Harris' sense are theoretically incompatible with the notion of 'languages' as scientifically describable objects identified by reocentric labels like German, Portuguese, Falkland Islands English, etc. This makes 'languages' second-order abstractions rather than first-order realities (LOVE, 2017). As a result of its rejection of the seminal orthodox distinction between 'language' as countable and 'language' as noncountable, the integrational understanding of language is not limited in the way that the surrogationalist and the structuralist conceptions are. The integrationist does not deny that human semiology is limited (in the sense that signs are by necessity limited, namely by virtue of the fact that they are species-specific signs), but will point out that an integrationist semiology is not limiting. For example, from an integrationist point of view, it makes no sense to embark on a search for the true or complete meaning of a word (HARRIS, 1998). The meaning of a word is limited to what I make that word mean in the present circumstances for the 
present purposes. That includes situations in which I do not make it mean anything because, for example, I do not know an unfamiliar word or situations in which I make a wild guess. How can I come to know what a word means if I have never encountered it before? Well, I can consult a dictionary. I can google it online. I can ask a person who happens to be present, etc. So the limits of what a word means are the limits set by the contingencies of the time-bound situation, i.e. by the communicational possibilities presently available to the sign-maker/-makers. These limits are not determined by an impartial authoritative institution (e.g. a language academy) but depend on the sign-maker's communicational biography. Thus, $A$ may know what the unfamiliar word means (he just came across the word yesterday and looked it up in a dictionary), while $B$ doesn't (he can't remember encountering it ever before). In other words, the idea of 'a language' equally known by all the members of the speech community is a theoretical fiction. However, once we concede that, what is left of the notion that 'languages' exist as psychological realities shared by a group of speakers?

The Harrisian position on word meaning is often confused with a semantic thesis called 'Humpty-Dumptyism'. The integrationist does not endorse Humpty-Dumpty's linguistic belief in already given words (determinacy of form) to which speakers assign completely idiosyncratic meanings (semantic indeterminacy). In other words, the integrationist does not think that lexicographers indulge in lexical fantasies when establishing word-meaning correspondences. Rather, they are engaged in a cultural practice that aims to reduce semantic indeterminacy. The lexicographical formula operates on the correspondence 'a:b' (e.g. moshpit:area nearest to the musician's stage'). The formula has some basis in the lexicographer's personal linguistic experience, which he/she assumes relates to the linguistic experience of others, too. This does not mean that the word moshpit cannot be used in a radically different way. Lewis Carroll's famous character Humpty-Dumpty did just that with the word glory. His perverse use of the word to mean a 'nice knock-down argument' shows that it is possible to create meaning on-the-spot, just as it is possible to create words on-the-spot. But until this particular use of the word glory can be related to by other people through their past linguistic experience (as far as we know, Alice is the only one to have been exposed to this use of glory), Humpty-Dumpty's innovation remains a macrosocially empty idiosyncrasy. At the same time, Humpty-Dumpty's linguistic nonsense is also a form of sign-making, and as such equally constrained by the three aforementioned parameters of communication. However, while it is true that integrationists believe that personal linguistic experience is our only "terra firma" (HARRIS, 1981, p. 204), this does not imply that my signmaking and other people's sign-making are insulated domains. For instance, linguistic experience is part of human (meta)discourse, through which something personal becomes public. In fact, as Harris (2013, p. 36) has argued, integrationism is not a form of solipsism. The rejection of the metaphysical thesis that signs are 'shared' does not make one a solipsist.

If signs are indeterminate in the integrationist sense, rather than determinate in the abstract (Saussurean) sense, the limits of language must vary with every individual and with every situation. However, there are general limits of a biomechanical, circumstantial, and macrosocial kind (HARRIS, 1998, p. 29), which transcend individual variation: The human ear only perceives within a certain range of frequency. We cannot utter two words at the same time. Reading and understanding a long and complex sentence takes time. I cannot have a proper conversation in Portuguese if I have never learnt any Portuguese. But no linguist can predict what the signs mean for a particular individual, i.e. sign-making is private. We can observe what others do and we can hear what they say, but how these activities relate to the agents' communicational histories is not open to disinterested observation. Sign-making is unobservable. The limits of language are always the limits of $m y$ language. In fact, the integrationist holds that the limits of my linguistic experience define the limits of my language. If I have never encountered a word before, or do not know what it means, I do not know how to integrate it in the present circumstances. In other words: I do not know what to 'do' with it (HARRIS, 1998, p. 91). I may or may not need to know for the present task at hand. There is no complete (i.e. contextless) knowledge of a word that one could ever grasp (pace Johnson-Laird). 'Knowing what to do' with a word, in Harris' sense, is about me making it a sign in relation to how I perceive the present communicational circumstances (including my assessment of the person/persons communicating with me). Harris (2009, p. 71) calls this knowledge "integrational proficiency". Whether I make it the 'right' kind of sign is a question that may or may not enter the picture subsequently, but it does not concern my first-order sign-making here-and-now.

Language is not a 'thing' that can be defined reocentrically, e.g. as a 'complex computational system'. For integrationists, language is something we $d o$, and as such, its only existence is through one's personal linguistic experience. 'Language' is also talked about, a topic of discourse, and as such, constrained by all sorts of macrosocial factors. What commonly counts as 'language' in the Global 
North may thus be very different from what counts as 'language' in the Global South (PENNYCOOK; MAKONI, 2019). Is there anything more general to say about linguistic experience? I'd venture to suggest that linguistic experience is an exclusively human experience. We cannot know how non-human beings experience anything, let alone whether they have any 'linguistic' experience. My dog constantly hears human voices and human sounds. Does my dog have personal linguistic experience as a result? In turn, I know I experience language on a daily basis. I also know other human beings experience language on a daily basis. Do I know that about each and every human being? Not from personal experience. But I have to assume that human beings all possess linguistic experience, however varied that experience undoubtedly is. That is, every human being has his/her personal communicational history, of which linguistic experience is an integral part. In terms of the limits of language, these limits have to be set anthropocentrically: applying the term 'language' to non-human creatures compels us to treat it as a reocentric label denoting different (species-specific) ontologies. Advocating a non-anthropocentric understanding of language may seem to open up the limits of our understanding of the phenomenon: 'Language' as we thought it was, which turns out to be much more than we imagined it to be (PENNYCOOK, 2018). However, the resulting expansion of the 'language' account, somewhat paradoxically, leads to a reductionist (and thus impoverished) view of language in the human realm. The integrationist argues in favour of an anthropocentric, non-segregational approach to the limits of language. Consequently, we need no 'scientific' definition of human language - that is, we leave it macrosocially open. In fact, human communities differ in their views of what counts as 'language' (HAUCK; HEURICH, 2018; PENNYCOOK; MAKONI, 2019).

\section{LANGUAGE AND RESPONSIBILITY}

In the Western tradition, the 'Language Myth', i.e. the theses that (i) languages are fixed-codes and (ii) linguistic communication serves to make the speaker's ideas known to the hearer, dictates that there are predefined limits to what words can mean. Here is what a famous neuroscientist, Sam Harris, said in his 2004 book The End of Faith about imaginary (Humpty-Dumpty) people he obviously regards as 'irrational' because they even contest the meanings of basic English words: "We are not free to mean whatever we want when using words like "poison" or "north" or "zero". Anyone who would lay claim to such entitlements should not be surprised when the rest of us stop listening to him”. (S. HARRIS, 2004, p. 51).

From a Southern perspective, of course, the whole discourse on 'rationality' is based on a northern ideology. It goes hand in hand with the so-called 'correspondence' theory of truth, which in turn leans on a reocentric semantics (HARRIS, 2004, p. 70). For the integrationist, there is another - more fundamental - reason why debates on human reasoning should not be conducted based on alleged linguistic agreements between speakers of the 'same language'. What words as used by individuals in concrete communicational situations mean is limited by circumstantial, biomechanical, and macrosocial factors. At the same time, they are made possible by these three factors. That is something that is lost completely on fixed-code theorists like Sam Harris. Language is always integrated with the rest of our ongoing activities. It is easy to condemn other people's linguistic usage (as Sam Harris does) when it does not conform to the (decontextualized) propositional contents expressed by sentences like 'poison is bad'. However, any utterance is a sponsored one, i.e. it is produced by someone, possibly in the presence of someone else, in some actual circumstance. What is more important than the question of whether 'we are free to use words in whatever way we want' is the integrationist semantic thesis that words mean what we make them mean in the here-and-now, for the present communicational purposes at hand. There is no word-meaning that is somehow 'external' to me, the meaning-maker. What you make my words mean is a totally different story: it is your interpretation of my words. How you interpret my words depends on you: Your signs are not my signs. What matters, in the end, is that we take linguistic responsibility for the signs we make, "at least to the extent", as Roy Harris (1998, p. 71) argues, "of being able to explain what we mean if called upon to do so". Asking the metalinguistic question 'What do you mean?' is one way for you to settle on a certain interpretation of my words (rather than another). If I want to know what someone meant by the words he/she used, the most straightforward course of action would be to ask him/her directly.

The notion of 'linguistic responsibility', it seems to me, opens up new avenues for linguistic inquiry. It is a notion tightly bound to the integrational conception of the sign as radically indeterminate in both form and meaning. The question of whether there are limits to language and what these limits are can only be pursued meaningfully by linguistic theorists after they have established (and declared) their semiological position. The question about the limits of language is not a theoretically neutral one. Neither are 
the questions 'What is language?', 'What is a language?', 'What is communication?', and 'What is a sign?'. Declaring one's philosophy of language is also a linguistically responsible course of action. In fact, the answers provided to these pivotal questions will determine the limits within which linguistic inquiry proceeds.

\section{REFERENCES}

HARRIS, R. The Language-Makers. London: Duckworth, 1980.

HARRIS, R. The Language Myth. London: Duckworth, 1981.

HARRIS, R. Signs, Language and Communication. London: Routledge, 1996.

HARRIS, R. Introduction to Integrational Linguistics. Oxford: Pergamon, 1998.

HARRIS, R. History, Science and the Limits of Language: An Integrationist Approach. Shimla: Indian Institute of Advanced Study, 2003.

HARRIS, R. The Linguistics of History. Edinburgh: Edinburgh University Press, 2004.

HARRIS, R. The Semantics of Science. London: Continuum Press, 2005.

HARRIS, R. Integrationist Notes and Papers 2006-2008. Gamlingay: Bright Pen, 2009.

HARRIS, R. Integrationist Notes and Papers 2009-2011. Gamlingay: Bright Pen, 2011.

HARRIS, R. Integrationist Notes and Papers 2012. Gamlingay: Bright Pen, 2012a.

HARRIS, R. Integrating Reality. Gamlingay: Bright Pen, 2012b.

HARRIS, R. Integrationist Notes and Papers 2013. Gamlingay: Bright Pen, 2013.

HARRIS, R. Integrationist Notes and Papers 2014. Gamlingay: Bright Pen, 2014.

HARRIS, R.; HUTTON, C. Definition in Theory and Practice. London: Routledge, 2007.

HARRIS, S. The End of Faith. New York \& London: Norton \& Company, 2004.

HAUCK, J.; HEURICH, G. Language in the Amerindian imagination: An inquiry into linguistic natures. Language \& Communication v. 63, p. 1-8, 2018.

JOHNSON-LAIRD, P. The psychology of understanding. In: ANTHONY, S. (ed.). The Nature and Limits of Human Understanding. London: Continuum, 2003. p. 1-46.

KUHN, T. The Structure of Scientific Revolutions. 2nd. ed. Chicago: Chicago University Press, 1970.

LOVE, N. On languaging and languages. Language Sciences, v. 61, p. 113-147, 2017.

PENNYCOOK, A. Posthumanist Applied Linguistics. London: Routledge, 2018. 
PENNYCOOK, A.; MAKONI, S. Innovations and Challenges to Applied Linguistics from the Global South. London \& New York: Routledge, 2019.

PROCTOR, R.; CAPALDI, E. J. Why Science Matters. Oxford: Blackwell Publishing, 2006.

SEALEY, A. Cats and categories - Reply to Teubert. Language and Dialogue, v. 4, n. 2, p. 299-321, 2014.

SEVERO, C.; MAKONI, S. Integrationism and the Global South: Songs as epistemic and ontological frameworks in language studies. In: MAKONI, Sinfree et al. (ed.). Integrational Linguistics and Philosophy of Language in the Global South. London: Routledge, 2021.p. 156-169.

\section{(c) (1) $\circledast$}

